\title{
EFFECT AND MECHANISM OF NANOSIZE COPPER OXIDE ON SOME PHYSICAL AND MECHANICAL PROPERTIES OF FLAKEBOARDS
}

\author{
Wei Gao ${ }^{1,2}$, Jinzhen Cao ${ }^{1}$, D. Pascal Kamdem ${ }^{3}$
}

\begin{abstract}
The effects of nanosize copper oxide and basic copper carbonate on the physical and mechanical properties of flakeboards were investigated according to ASTM Standard D-1037, and the curing process of phenol formaldehyde (PF) resin containing copper compounds was further investigated using dynamic differential scanning calorimetry (DSC). The results showed that nanosize copper oxide had no or slightly beneficial effects on the mechanical properties and dimensional stability of the flakeboards. While basic copper carbonate increased thickness swelling and water absorption to some extent, the difference was not statistically significant. The DSC results indicated that the comparable activation energy and reaction enthalpy, obtained from nanosize copper oxide treated samples, contributed to the higher degree of conversion of PF resin and undiminished bonding strength of flakeboards, which is probably related to the acceleration of the addition reactions taking place among small molecules in PF resin and the enhancement of heat transfer of composite mat caused by nanosize copper oxide.
\end{abstract}

Keywords: nanosize copper oxide, basic copper carbonate, flakeboard, physical and mechanical properties, differential scanning calorimetry (DSC).

\section{INTRODUCTION}

Development of oriented strand board (OSB) has been limited to indoor utilizations where biological deterioration is not critical. Protection against biological degrading agents may promote its outdoor applications. One proposed strategy for achieving this is the use of naturally durable wood species as the raw material to produce OSB. However, those wood species have limited availability and inconsistent decay resistance which varies from sapwood to heartwood within the same log, within species, with the sylvicultural practices and the provenance of the log (Amusant et al. 2009). A more practical way for improving biological performance is to use preservatives in OSB (Sean et al. 1999, Goroyias and Hale 2004, Donath et al. 2008). They used inorganic and organic formulations containing copper, borate or zinc. Cheney et al. (2009) found that the copper based preservatives ( $\mathrm{Cu}$ ammonium acetate, $\mathrm{Cu}$ diammine acetate, $\mathrm{Cu}$ diammine carbonate, basic $\mathrm{Cu}$ carbonate) reduced weight losses of aspen strandboards caused by brown-rot fungus $G$. trabeum or white-rot fungus $T$. versicolor to below $10 \%$. Copper is a well established fungicide and recently it was used in its copper carbonate micronized form in combination with an organic biocides to protect wood (Barnes et al. 2008, Cookson et al. 2008). Stirling et al. (2008) reported that wood treated with micronized copper quat (MCQ) is also resistant to soft rot decay fungi. This resistance is likely due to the soluble copper released in the cell wall of treated wood. Barnes et al. (2008) noted that the mechanical properties of micronized copper preservative systems treated southern pine were not affected. Although micronized copper has been widely used to treat solid wood and their efficacy on the biological resistance and/or strength properties was well established, their applications in wood composites are still limited (Vidrine et al. 2008, Vidrine et al. 2009). The reason was partly due to the adverse effect of preservatives on physical and mechanical properties of wood composites because their potential interaction or interference with adhesive. 
This study examines the feasibility of incorporating solid copper oxide $(\mathrm{CuO})$ nanoparticles in the adhesive mix during the laboratory manufacture of flakeboard, and then evaluates the mechanical and physical properties as indication of compatibility. To achieve this objective, several loading levels of nanosize copper oxide were added in a commercial PF adhesive and the properties of the so-made flakeboards were compared to that of commercial origin made with similar glue and flakes. DSC was used to investigate the effect of $\mathrm{CuO}$ nanoparticles on the curing process of phenol formaldehyde (PF) resin.

\section{MATERIALS AND METHODS}

\section{Panel Manufacturing and Testing}

The flakes used in this study were composed of mixed wood species (aspen 55\%, pine 20\%, soft maple 20\%, and hard maple 5\%), which were obtained from Weyerhaeuser plant located in Grayling, Michigan, USA. The average size of the flakes was $0.5 \pm 0.1 \mathrm{~mm}$ in thickness, $15 \pm 5 \mathrm{~mm}$ in width and $100 \pm 10 \mathrm{~mm}$ in length along the direction parallel to grain. Aqueous phenol formaldehyde (PF) resin GP 70CR66 (Georgia-Pacific Resins, Inc.) with 54\% solid content was also obtained from Weyerrhaueser, which is the resin used routinely to manufacture commercial OSB. Nanoparticle size copper (cupric) oxide $(\mathrm{CuO})$ was obtained from Johnson Mathey Company. It was a 23-37 nm particle size Aps (air plasma spray) powder with a nominal specific surface area of 25 to $40 \mathrm{~m}^{2} / \mathrm{g}$. Basic copper (cupric) carbonate $\left(\mathrm{CuCO}_{3} \cdot \mathrm{Cu}(\mathrm{OH})_{2}\right)$ labeled as $\mathrm{BCC}$, was purchased from Aldrich Chemical Company and used as received for comparative purposes.

Nanosize $\mathrm{CuO}$ was mixed with PF resin at three loadings of $0.12,0.25$, and $0.49 \%$ (w/w, based on flakes), respectively and $\mathrm{BCC}$ was at $0.68 \%$ (equivalent to $0.49 \% \mathrm{CuO}$ ). Moisture content of the flakes was about $3 \pm 0.5 \%$. The resin was sprayed on flakes at a ratio of $3.5 \% \mathrm{w}$ : $\mathrm{w}$ of solid resin. Adhesive coated flakes were removed from the rotary blender and used to hand form a mat of flakes with random orientations to achieve a target density after pressing and curing at temperature of $204^{\circ} \mathrm{C}$ at $4.8 \mathrm{Mpa}$ for 300s. Five panels were made for each treatment group. An untreated control was also prepared for comparison. Panels with nominal size of 9.8 by 406 by $406 \mathrm{~mm}$ with target density of $650 \mathrm{~kg} / \mathrm{m}^{3}$ were trimmed by removing the edges to $8 \times 300 \times 300 \mathrm{~mm}$ panels to avoid low density edges. Samples were conditioned at $22 \pm 2^{\circ} \mathrm{C}$ and $70 \pm 2 \%$ relative humidity (RH) to constant weight before testing their physical and mechanical properties, which were thickness swelling at edge (TS), water absorption (WA), internal bond strength (IB), modulus of rupture (MOR), and modulus of elasticity (MOE) (bending flatwise) were assessed using ASTM D1037 (ASTM 1999).

The effects of nanosize $\mathrm{CuO}$ and/or copper carbonate were established by evaluating the differences between properties of treatments and the control groups using one-way ANOVA analysis at 95\% confidence level with SPSS 16.0 (SPSS Inc., Chicago, Illinois, USA).

\section{Dynamic DSC Scanning and Calculation}

DSC60 (Shimadzu, Japan) equipped with a TA-60 thermal analysis system was used to monitor the effect of the addition of copper oxide nanoparticles and copper carbonate on the curing of the commercial phenol formaldehyde OSB grade resin used in this work. The temperature and heat calibrations of DSC were performed by using standards of indium, tin, lead and zinc. PF sample of $10 \pm 2 \mathrm{mg}$ was placed in a sealable aluminum capsule with vapor pressure limit at $4.9 \mathrm{MPa}$. The weight of the sealed samples was taken before and after DSC testing to monitor weight loss during the testing. Nitrogen gas at $10 \mathrm{ml} /$ min was used at temperature of 40 to $250^{\circ} \mathrm{C}$ with heating rates of 5,10 and $20^{\circ} \mathrm{C} / \mathrm{min}$. Three replicates were scanned for each condition. The total area under the exothermal curve, based on the extrapolated baseline was used to calculate the reaction enthalpy of curing using TA-60 thermal analysis software (Shimadzu Inc., Kyoto, Japan), and the standard method ASTM E698-01 (ASTM 2001) to estimate the activation energy $\mathrm{E}_{698}$ as well. 


\section{RESULTS AND DISCUSSION}

\section{Physical and Mechanical Properties}

The properties of flakeboards laboratory manufactured with nanosize copper oxide nanoparticles or copper carbonate added in the glue mix and the oriented strand board from commercial source at PF ratio of $3.5 \%$ are listed in table 1 .

Table 1. Physical and mechanical properties of flakeboards made with copper oxide nanoparticles or basic copper carbonate added in the glue mix.

\begin{tabular}{|c|c|c|c|c|c|c|c|c|}
\hline \multirow[t]{2}{*}{ Treatment } & \multirow{2}{*}{$\begin{array}{l}\text { Average } \\
\text { Density } \\
\left(\mathrm{kg} / \mathrm{m}^{3}\right)\end{array}$} & \multirow{2}{*}{$\begin{array}{c}\mathrm{IB} \\
(\mathrm{MPa})\end{array}$} & \multirow[t]{2}{*}{$\begin{array}{l}\text { MOR } \\
(\mathrm{MPa})\end{array}$} & \multirow[t]{2}{*}{$\begin{array}{l}\mathrm{MOE} \\
(\mathrm{GPa})\end{array}$} & \multicolumn{2}{|c|}{$\begin{array}{l}\text { Water absorption } \\
\qquad \%)\end{array}$} & \multicolumn{2}{|c|}{$\begin{array}{l}\text { Thickness } \\
\text { swelling } \\
(\%)\end{array}$} \\
\hline & & & & & $2 \mathrm{~h}$ & $24 \mathrm{~h}$ & $2 \mathrm{~h}$ & $24 \mathrm{~h}$ \\
\hline PF Control & $678(24)$ & $\begin{array}{c}0.33 \\
(0.08) \\
a b\end{array}$ & $\begin{array}{c}28.6(5.0) \\
a\end{array}$ & $\begin{array}{c}3.89(0.84) \\
\mathrm{a}\end{array}$ & $\begin{array}{c}46.3 \\
(4.6) \mathrm{ab}\end{array}$ & $\begin{array}{l}60.5 \\
(2.4) \mathrm{a}\end{array}$ & $\begin{array}{l}24.9 \\
(2.9) \mathrm{a}\end{array}$ & $\begin{array}{c}28.6 \\
(3.4) \mathrm{a}\end{array}$ \\
\hline $\begin{array}{c}\mathrm{PF}+\mathrm{CuO} \\
0.12 \%\end{array}$ & $680(36)$ & $\begin{array}{c}0.33 \\
(0.06) \\
a b\end{array}$ & $\begin{array}{c}36.7(7.7) \\
\mathrm{a}\end{array}$ & $\begin{array}{c}4.29(0.67) \\
\mathrm{a}\end{array}$ & $\begin{array}{c}45.9 \\
(5.4) \mathrm{ab}\end{array}$ & $\begin{array}{c}59.1 \\
(4.7) \mathrm{a}\end{array}$ & $\begin{array}{c}22.9 \\
(3.7) \mathrm{a}\end{array}$ & $\begin{array}{c}27.4 \\
(4.1) \mathrm{a}\end{array}$ \\
\hline $\begin{array}{c}\mathrm{PF}+\mathrm{CuO} \\
0.25 \%\end{array}$ & 663 (39) & $\begin{array}{c}0.33 \\
(0.08) \\
a b\end{array}$ & $\begin{array}{c}29.0(5.1) \\
\mathrm{a}\end{array}$ & $\begin{array}{c}3.81(0.66) \\
a\end{array}$ & $\begin{array}{c}46.4 \\
(6.5) \mathrm{ab}\end{array}$ & $\begin{array}{c}57.6 \\
(4.1) \mathrm{a}\end{array}$ & $\begin{array}{c}22.5 \\
(2.6) \mathrm{a}\end{array}$ & $\begin{array}{c}26.0 \\
(3.0) \mathrm{a}\end{array}$ \\
\hline $\begin{array}{c}\mathrm{PF}+\mathrm{CuO} \\
0.49 \%\end{array}$ & $669(24)$ & $\begin{array}{c}0.37 \\
(0.07) \\
\mathrm{bc}\end{array}$ & $\begin{array}{c}33.2(6.2) \\
\mathrm{a}\end{array}$ & $\begin{array}{c}4.46(0.70) \\
a\end{array}$ & $\begin{array}{c}49.0 \\
(6.4) \mathrm{ab}\end{array}$ & $\begin{array}{c}59.4 \\
(4.8) \mathrm{a}\end{array}$ & $\begin{array}{c}23.2 \\
(3.0) \mathrm{a}\end{array}$ & $\begin{array}{c}26.1 \\
(4.3) \mathrm{a}\end{array}$ \\
\hline $\begin{array}{c}\mathrm{PF}+\mathrm{BCC} \\
0.68 \%\end{array}$ & $686(19)$ & $\begin{array}{l}0.27 \\
(0.05) \\
\mathrm{ab} \\
\end{array}$ & $\begin{array}{c}29.9(6.2) \\
\mathrm{a}\end{array}$ & $\begin{array}{c}4.20(0.66) \\
a\end{array}$ & $\begin{array}{c}52.2 \\
(4.0) \mathrm{b}\end{array}$ & $\begin{array}{c}62.4 \\
(3.2) \mathrm{a}\end{array}$ & $\begin{array}{c}25.6 \\
(3.5) \mathrm{a}\end{array}$ & $\begin{array}{l}29.5 \\
(5.1) \mathrm{a}\end{array}$ \\
\hline \multirow{2}{*}{$\begin{array}{l}\text { Weyerhaeu } \\
\text { ser }\end{array}$} & \multirow{2}{*}{675 (19) } & \multirow{2}{*}{$\begin{array}{c}0.20 \\
(0.06) \\
a\end{array}$} & $\begin{array}{c}34.1^{\|}(2.9) \\
\mathrm{a} \\
\end{array}$ & $\begin{array}{c}4.33 \|(0.75) \\
\mathrm{a} \\
\end{array}$ & \multirow{2}{*}{$\begin{array}{c}40.5 \\
(5.0) \mathrm{a}\end{array}$} & \multirow{2}{*}{$\begin{array}{c}72.6 \\
(2.7) \mathrm{b}\end{array}$} & \multirow{2}{*}{$\begin{array}{c}14.2 \\
(5.7) \mathrm{b}\end{array}$} & \multirow{2}{*}{$\begin{array}{c}28.2 \\
(5.7) \mathrm{a}\end{array}$} \\
\hline & & & $\begin{array}{c}16.6^{\perp}(1.5) \\
b\end{array}$ & $\begin{array}{c}1.41^{\perp}(0.24) \\
b\end{array}$ & & & & \\
\hline
\end{tabular}

Values represent means of 5 replicates per treatment, while figures in parentheses are the standard deviations. Within columns, means with the same letters indicate that the difference is statistically insignificant using Tukey's Studentized Range Test ( $\alpha=0.05$ ). The superscripts of "\|l"and " " $"$ represent the flexural strengths measured along the parallel and perpendicular directions of oriented flakes, respectively.

The average IB for panels made with unmodified PF was $0.33 \mathrm{MPa}$. For those panels containing lower loading levels of copper oxide nanopaticles, the IB of the panels were unchanged, while increasing the loading of copper oxide nanoparticles to $0.49 \%$, the IB of the panel increased to $0.37 \mathrm{MPa}$. However, the difference was insignificant compared to the unmodified PF control was insignificant at $95 \%$ interval of confidence as revealed by ANOVA test. The introduction of $0.68 \% \mathrm{BCC}$ to panels caused a decrease in IB from $0.33 \mathrm{MPa}$ to $0.27 \mathrm{MPa}$, but again this difference was not significant. The lowest IB value was obtained from the commercial OSB board, which may be explained by the different process variables between industrial and laboratory manufacture such as pressure level and duration. 
The average values of flexural MOR and MOE mostly increased after adding copper oxide nanoparticles or BBC to PF adhesive compared with unmodified control, suggesting that the incorporation of copper in the adhesive had little influence on the flexural properties of flakeboards, which is consistent with previous reports on the effect of micronized copper oxide on aspen flakeboards using PF resin as a binder (Vidrine et al. 2008).

The dimensional stability which includes the values of WA and TS after 2 and 24 hours' immersion in distilled water at $20 \pm 1^{\circ} \mathrm{C}$ was shown in table 1 and figure 3. No significant difference was detected among groups of boards made in the laboratory by using unmodified PF or PF modified with either of the copper compounds. While compared to the commercially made boards, the difference is significant in some cases, for example, the WA after $24 \mathrm{~h}$ and the TA after $2 \mathrm{~h}$. Although the WA after $2 \mathrm{~h}$ of laboratory made flakeboards with PF modified with $\mathrm{CuO}$ nanoparticles showed no significant difference with commercial OSB due to the wide standard deviation, the average values of WA after $2 \mathrm{~h}$ were consistently trend of higher than that of commercial OSB. However, the WA after $24 \mathrm{~h}$ showed the reserves result; namely, the WA of laboratory made flakeboards was lower than that of commercial OSB. The reason was considered to be related with the addition of wax in the formulation of commercial OSB, which would hinder water absorption at first but then be overcome by continued soaking. The lower WA after $24 \mathrm{~h}$ of laboratory made flakeboards suggested that both $\mathrm{CuO}$ nanoparticles and $\mathrm{BCC}$ had an effect on reducing water sorption after long duration. Correspondingly, the TA was also lower after $2 \mathrm{~h}$ for commercial OSB but after $24 \mathrm{~h}$ there was no significant difference between all groups. This trend was similar to the results in a previous report (Jusoh et al. 2005). Compared the average WA and TS values of CuO nanoparticles $(0.49 \%)$ with $\mathrm{BCC}(0.68 \%)$ at the same copper concentration, it can be clearly found that the values of the boards containing $\mathrm{CuO}$ nanoparticles are slightly lower than that of the boards with BCC without statistical significance.

From the above discussion, we can draw the conclusion that nanosize $\mathrm{CuO}$ and basic copper carbonate can be incorporated in the glue mix at levels used in this work with no significant negative effect on the mechanical properties and even with some slight improvement in dimensional stability of flakeboard. The mechanism to explain the performance was further investigated by using DSC to clarify the curing process of $\mathrm{PF}$ adhesive containing copper oxide nanoparticles and $\mathrm{BCC}$.

\section{Dynamic DSC Analysis}

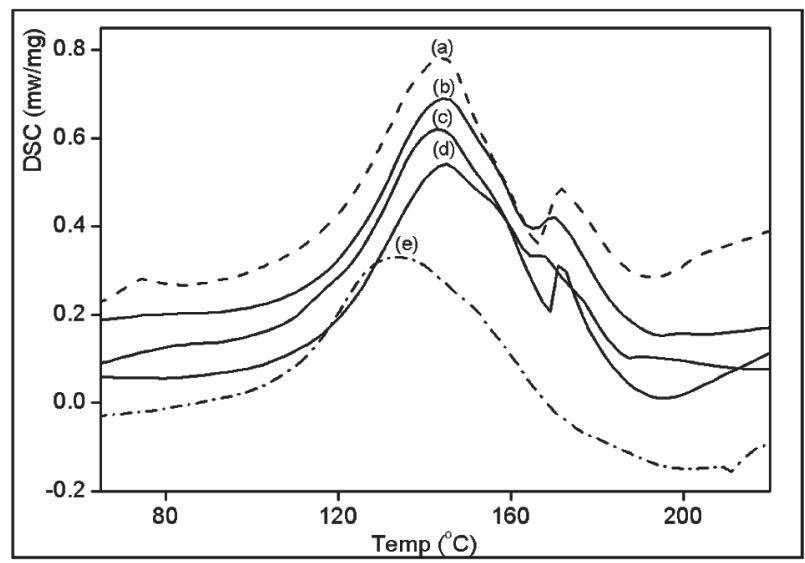

Figure 1. Dynamic DSC curves of PF control (a), PF with nanosize copper oxide at loading levels of $0.12 \%$ (b), $0.25 \%$ (c), and $0.49 \%$ (d), and PF with basic copper carbonate $0.68 \%$ (e) at a heating rate of $10^{\circ} \mathrm{C} / \mathrm{min}$. 
Figure 1 demonstrates the dynamic scanning calorimeter (DSC) curves of PF control and PF resin containing $\mathrm{CuO}$ nanoparticles and $\mathrm{BCC}$ at a heating rate of $10^{\circ} \mathrm{C} / \mathrm{min}$. The major exothermal peak for $\mathrm{PF}$ control appeared at $144.5^{\circ} \mathrm{C}$, followed by another peak at about $171.7^{\circ} \mathrm{C}$. The onset curing temperature was close to $108.5^{\circ} \mathrm{C}$. With the addition of nanosize $\mathrm{CuO}$, the first peak temperature similar to the exothermal peak of PF control did not change, but the other peak initially at $171.7^{\circ} \mathrm{C}$ for PF control shifted slightly to $170.0^{\circ} \mathrm{C}$. However, the addition of $0.68 \% \mathrm{BCC}$ to the PF adhesive resulted in a shift of the exothermic peak to $133.7^{\circ} \mathrm{C}$ without an observable second peak. More detailed DSC tests were run at different heating rates to elucidate the effect of the addition of $\mathrm{CuO}$ nanoparticles and $\mathrm{BCC}$ as represented in figure 2.
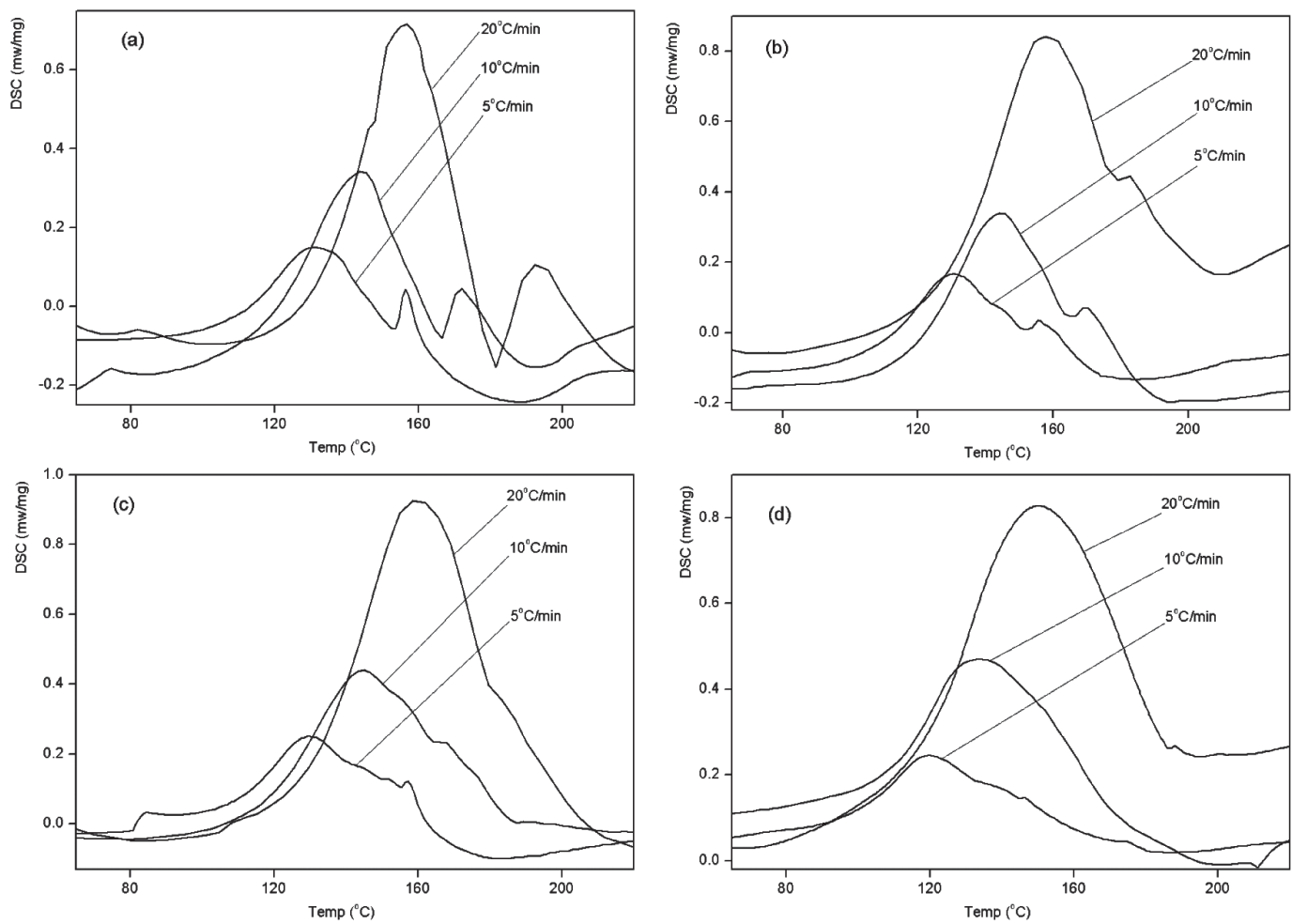

Figure 2. Dynamic DSC curves of control PF resin (a) and PF resin with nanosize copper oxide at concentration of $0.12 \%$ (b), $0.49 \%$ (c), and basic copper carbonate $0.68 \%$ (d) at heating rate of 5,10 and $20{ }^{\circ} \mathrm{C} / \mathrm{min}$ respectively.

It is clear from figure 2 that $\mathrm{CuO}$ nanoparticles and $\mathrm{BCC}$ have different effects on the thermal behavior of PF during curing from room temperature to $200^{\circ} \mathrm{C}$. Table 2 lists the DSC parameters of PF control, PF with different loadings of nanosize copper oxide, and PF with BCC computed from DSC curves according to ASTM E698-01 (ASTM 2001). The energy of activation $\left(\mathrm{E}_{698}\right)$, illustrating the chemical reactivity of the curing reactions, was obtained from the exothermic peak from the DSC curves at three heating rates (Figure 2). 
Table 2. DSC parameters of $\mathrm{PF}$ control, $\mathrm{PF}+\mathrm{CuO}$, and $\mathrm{PF}+\mathrm{BCC}$.

\begin{tabular}{|l|l|l|l|l|l|}
\hline \multirow{2}{*}{ Sample } & \multirow{2}{*}{$\begin{array}{l}\mathrm{H} \\
(\mathrm{J} / \mathrm{g})\end{array}$} & $\begin{array}{l}E_{698} \\
(\mathrm{KJ} / \mathrm{mol})\end{array}$ & $5\left({ }^{\circ} \mathrm{C} / \mathrm{min}\right)$ & $10\left({ }^{\circ} \mathrm{C} / \mathrm{min}\right)$ & $20\left({ }^{\circ} \mathrm{C} / \mathrm{min}\right)$ \\
\hline PF Control & $135.67(35.47) \mathrm{a}$ & 72.10 & 130.99 & 144.36 & 156.19 \\
\hline $\mathrm{PF}+\mathrm{CuO} 0.12 \%$ & $138.72(41.55) \mathrm{a}$ & 66.00 & 130.44 & 144.58 & 157.90 \\
\hline $\mathrm{PF}+\mathrm{CuO} 0.25 \%$ & $148.26(20.38) \mathrm{b}$ & 65.97 & 130.01 & 143.00 & 157.70 \\
\hline $\mathrm{PF}+\mathrm{CuO} 0.49 \%$ & $150.60(22.06) \mathrm{b}$ & 65.90 & 130.90 & 144.90 & 158.48 \\
\hline $\mathrm{PF}+\mathrm{BCC} 0.68 \%$ & $125.68(26.01) \mathrm{c}$ & 55.77 & 119.66 & 133.73 & 150.26 \\
\hline
\end{tabular}

Values represent means of 3 replicates per treatment, while figures in parentheses are the standard deviations. In a same column the same followed alphabets represent that the difference is statistically insignificant using Tukey's Studentized Range Test $(\alpha=0.05)$.

In general, the activation energy of modified PF is lower than that of PF control. Further more, the addition of $0.68 \%$ copper carbonate caused greater reduction on activation energy than $0.49 \%$ nanosize $\mathrm{CuO}$. It indicated that both copper compounds improved the cure reactions of PF resin. The probable reason is that copper oxide is a Lewis base, which may accelerate the addition reactions taking place among small molecules in PF resin. It is characterized by the formation of chelates as transient compounds according to the following formula (Pizzi 1979 a,b,c):

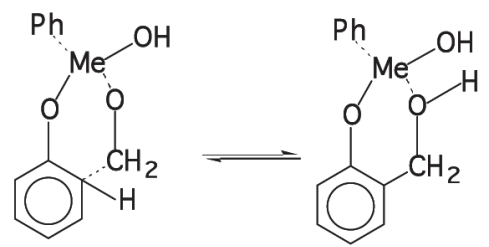

As the cure reactions of PF resin are typically exothermic, it can be confirmed that the reaction enthalpy, or in the other words, the amount of heat released in the reaction, is proportional to the degree of conversion during the curing process or the cross-linking created in the adhesive self-condensation (Vázquez et al. 2006). The DSC results from table 2 illustrated that the reaction enthalpy increased obviously with the addition of nanosize copper oxide in the curing system. Moreover, the highest reaction enthalpy value of $152.40 \mathrm{~J} / \mathrm{g}$ was obtained by the sample of PF with $0.49 \%$ copper oxide. This indicates that the final degree of conversion of the curing reaction for $\mathrm{PF}$ with nanosize $\mathrm{CuO}$ is higher than that of PF control. This is also evidence for the similar or slightly improved dimensional stability of the corresponding flakeboards (Table 1). The reason was considered to be related to the increased thermal conductivity of flakeboard mat caused by the addition of nanosize copper oxide since the reported data showed that the thermal conductivity of $\mathrm{CuO}$ particle is $20 \mathrm{~W} / \mathrm{Mk}$ (Kwak and Kim 2005), while the air dried wood was between 0.070 to $0.407 \mathrm{~W} / \mathrm{Mk}$ (Yin 1996). Therefore, both heat transfer of the flakeboard mat and the curing process of PF resin were enhanced, and the final mechanical properties of flake board were sometimes slightly improved as well. 


\section{CONCLUSIONS}

Nanosize copper oxide had no or slightly beneficial effects on the mechanical properties and dimensional stability of flakeboard. While basic copper carbonate increased thickness swelling and water absorption to some extent, the difference was not statistically significant. The DSC results indicated that the activation energy of PF cure decreased significantly with the addition of $0.68 \%$ basic copper carbonate, and the reaction enthalpy reduced at the same time, which resulted in the relatively lower bond strength of for treated flakeboards. However, comparable activation energy and reaction enthalpy were obtained from PF resin control and nanosize copper oxide treated samples, indicating that application of nanosize copper oxide resulted in the higher degree of conversion of PF resin and undiminished bond strength. The biological resistance of nanosize copper oxide and basic copper carbonate treated flakeboards will be examined in further study.

\section{ACKNOWLEDGEMENT}

The authors wish to acknowledge the International Research Group on Wood Protection (IRG-WP) for a Travel Award that allowed Mr. Wei Gao to complete the experiment of this work in Michigan State University. We also thank Weyerhaeuser for providing flakes and adhesive to this research.

\section{REFERENCES}

Amusant, N.; Arnould, O.; Pizzi, A.; Depres, A.; Mansouris, R. H.; Bardet, S.; Baudasse, C. 2009. Biological properties of an OSB eco-product manufactured from a mixture of durable and non durable species and natural resins. European Journal of Wood and Wood Products 67(4): 439-447.

ASTM. 1999. Standard test method for evaluating properties of wood-based fiber and particle panel material. D1037-99. ASTM International. West Conshohocken, USA.

ASTM. 2001. Standard test method for arrhenius kinetic constants for thermally unstable materials. ASTM E698-01. ASTM International. West Conshohocken, USA.

Barnes, H. M.; Lindsey, G. B.; Hill, J.; Pompeo, M.; Hodge, R. 2008. Bending properties of southern pine treated with micronized preservative systems. The $39^{\text {th }}$ Annual Meeting of International Research Group on Wood Preservation, Istanbul, Turkey.

Cookson, L. J.; Creffield, J. W.; McCarthy, K. J.; Scown, D. K. 2008. Australian trials on the efficacy of micronized copper. The $39^{\text {th }}$ Annual Meeting of International Research Group on Wood Preservation, Istanbul, Turkey.

Donath, S.; Spetmann, P.; Jaetsch, T.; Zahlmann, T. 2008. Protection of OSB against termites by incorporation of different actives via glue line treatment. The $39^{\text {th }}$ Annual Meeting of International Research Group on Wood Preservation, Istanbul, Turkey.

Goroyias, G. J.; Hale, M. D. 2004. The mechanical and physical properties of strand boards treated with preservatives at different stages of manufcture. Wood Science and Technology 38(2): 93-107.

Jusoh, I. B.; Nzokou, P.; Kamdem, P. 2005. The effect of silicone on some properties of flakeboard. Holz Als Roh-Und Werkstoff 63(4): 266-271. 
Kwak, K.; Kim, C. 2005. Viscosity and thermal conductivity of copper oxide nanofluid dispersed in ethylene glycol. Korea-Australia Rheology Journal 17(2): 35-40.

Pizzi, A. 1979(a). Phenolic resins by reactions of coordinated metal ligands. Journal of Polymer Science: Polymer Letters Edition 17(8): 489-492.

Pizzi, A. 1979(b). Phenol and tannin-based adhesive resins by reactions of coordinated metal ligands, Part1: phenolic chelates. Journal of Polymer Science 24(5): 1247-1256

Pizzi, A. 1979(c). Phenol and tannin-based adhesive resins by reactions of coordinated metal ligands, Part II: Tannin adhesives preparation, characteristics and application. Journal of Polymer Science 24(5): $1257-1268$.

Sean, T.; Brunette, G.; Côté, F. 1999. Protection of oriented strandboard with borate. Forest Products Journal 49(6): 47-51.

Stirling, R.; Drummond, J.; Zhang, J.; Ziobro, R. J. 2008. Micro-distribution of micronized copper in southern pine. The $39^{\text {th }}$ Annual Meeting of International Research Group on Wood Preservation, Istanbul, Turkey.

Vázquez, G.; González-Álvarez, J.; Antorrena, G. 2006. Curing kinetics of phenol formaldehyde resin and wood-resin interactions in the presence of wood substrates. J. Therm. Anal. Calorim 84(3): 651-654.

Vidrine, C.; Kamke, F.; Preston, A.; Morrell, J. J. 2009. The effects of copper-based preservative technologies on the resistance of aspen strandboards to biological degradation. Wood and Fiber Science 41(3): 211-219.

Vidrine, C.; Kamke, F. A.; Morrell, J.; Preston, A. 2008. Preserving panels by furnish addition of copper compounds: Effects on panel properties. American wood protection association.

Yin, S. 1996. Wood science. China Forestry Press. Beijing, China. 